\title{
Evaluation of Stocking All Female Largemouth Bass (Micropterus salmoides) in Alabama (USA) Ponds
}

\author{
Michael J. Maceina, Steven M. Sammons, Ronald P. Phelps \\ School of Fisheries, Aquaculture, and Aquatic Sciences, Auburn University, Auburn, Alabama, USA \\ Email:maceimj@auburn.edu
}

Received 19 April 2016; accepted 10 June 2016; published 13 June 2016

Copyright $@ 2016$ by authors and Scientific Research Publishing Inc.

This work is licensed under the Creative Commons Attribution International License (CC BY).

http://creativecommons.org/licenses/by/4.0/

(c) (i) Open Access

\begin{abstract}
Excessive largemouth bass (Micropterus salmoides) recruitment in small impoundments leads to density-dependent growth depression, causing populations to have length distributions skewed towards smaller fish. To address this issue, we conducted three trials that evaluated stocking all female largemouth bass (F-LMB) in two small Alabama ponds ( 0.5 and 2.0 ha) where the drainage basin was isolated. Age-1 fish were individually identified for sex using a micro pipette inserted in the urogenital pore, tagged, and stocked at 38-40 F-LMB/ha into ponds that contained pre-established sunfish (Lepomis spp.) populations. Female largemouth bass were collected with electrofishing, angling, and rotenone over a 2.5- to 5-year period among the three trials. Sex was correctly identified for 179 of the 180 F-LMB stocked. One male was detected in the first trial which resulted in successful largemouth bass reproduction and this trial was terminated after two years. Growth was rapid the first 2 years after stocking as 3-year-old fish reached an average of 429 to $459 \mathrm{~mm}$ and 1.37 to $1.66 \mathrm{~kg}$ in all 3 trials. However, 2 years after stocking, growth was nil in the second trial even though relative weights of F-LMB were generally greater than 100 . In this second trial, removal of about $30 \%$ of the F-LMB inhabiting the pond and stocking small Nile tilapia Oreochromis niloticus $(25-75 \mathrm{~mm})$ resulted in average weights increasing from 1.30 to $2.34 \mathrm{~kg}$ in 1 year. Growth of F-LMB continued in the third trail, and average size approached $500 \mathrm{~mm}$ and $2.2 \mathrm{~kg}$ three years after stocking. Annual survival rates of F-LMB were high and ranged from 0.78 to 0.93 among the 3 trials. Stocking F-LMB offers an attractive alternative in ponds to create a low density largemouth bass population that displays fast growth and high survival when catch-and-release fishing is primarily practiced.
\end{abstract}

\section{Keywords}

Largemouth Bass, Relative Weight, Growth, Survival, Ponds, Program MARK 


\section{Introduction}

For more than a century, small impoundments or ponds ( $<40 \mathrm{ha}$ ) have provided recreational sport fishing in the USA. About 4.5 million ponds that cover about 3.0 million ha are found in the contiguous USA [1]. The last survey [2] where types of freshwater angling were categorized found $35 \%$ of the 30.1 million USA anglers fished in ponds less than 4.2 ha.

Largemouth bass (Micropterus salmoides) and bluegill (Lepomis macrochirus) are the species most commonly stocked into ponds [3], and provide both recreational opportunities and a source of food. However, many freshwater anglers today wish to catch larger fish (primarily largemouth bass), with fish consumption less of a priority. Although overharvest of fish was once the primary issue in small impoundment management, now lack of harvest is the most common issue creating undesirable fisheries [1]. Low largemouth bass harvest in ponds can lead to overcrowding, resulting in stunted growth, poor body condition, and a population skewed towards smaller fish [4].

New and innovative approaches are now being used to meet different angler expectations as traditional management of sport fisheries in ponds is changing [3] [5]. To improve size and growth of largemouth bass, prey fish can be stocked, but these stockings have resulted in mixed success [6]. Alternatively, largemouth bass can be removed from ponds via angling or electrofishing, but even liberal largemouth bass annual harvest rates of 10 - $20 \mathrm{~kg} / \mathrm{ha}$ may be insufficient to reduce the density of largemouth bass and improve growth and size structure. Moderate to high recruitment of stock length (20 - $30 \mathrm{~cm}$ total length; TL) or smaller largemouth bass compounds this problem of overabundance. Consumption by small $(<25 \mathrm{~cm} \mathrm{TL})$ largemouth bass of bluegill in Alabama ponds was $130-160 \mathrm{~kg} \cdot \mathrm{ha}^{-1} \cdot \mathrm{yr}^{-1}$ which constituted a high proportion of bluegill production [7]. After three years, largemouth bass were removed from these same ponds at an annual rate of $14-15 \mathrm{~kg} / \mathrm{ha}$, but these populations were still characterized by poor body condition and length distributions skewed towards smaller fish, due to excessive largemouth bass recruitment [8]. Removal of stock length or smaller largemouth bass with angling and/or electrofishing is not selective towards smaller fish, is labor intensive [4], and can be expensive. Furthermore, removal of sufficient numbers of small $(<30 \mathrm{~cm})$ largemouth bass to create balance in ponds is difficult when recruitment of these fish is high [9]. Low-dose shoreline rotenone treatments after largemouth bass spawn can reduce recruitment in many instances, but require professional applicators, and can result in the death of adult largemouth bass and other desirable species [10]. Thus, rotenone is not commonly used to suppress largemouth bass reproduction in ponds.

Creating a largemouth bass fishery in ponds where recruitment is limited or is non-existent is an attractive management alternative. Triploid largemouth bass are presumably sterile and have been successfully produced [11], but have received limited evaluation [12]. Obviously, success of stocking all female largemouth bass to eliminate reproduction requires a closed basin to prevent introduction of males. Female largemouth bass can also provide a desirable fishery as these fish grow faster and reach larger sizes than males [3] [6]. Female largemouth bass (F-LMB) can be produced with treatment of feminizing hormones, but these fish are not approved for commercial production by the US Food and Drug Administration. Alternatively, sex of young adult fish can be identified using non-lethal techniques such as catheterization or ultrasound [13] [14]. Stocking of sterile or all female largemouth bass is a viable strategy to prevent recruitment [6], but requires research, as little information exists [15].

The objectives of this study were to evaluate F-LMB stockings in three pond trials. In these ponds, we estimated density, biomass, survival, growth, and body condition (weight:length ratio) or relative weight $\left(\mathrm{W}_{\mathrm{r}}\right)$ of F-LMB. We also assessed the accuracy of correctly identifying gender of largemouth bass. Our goal was to produce relatively low-density largemouth bass populations that only contained large individuals (memorable length $\geq 508 \mathrm{~mm}$ ) and displayed $\mathrm{W}_{\mathrm{r}} \mathrm{s}$ over 100 . To obtain this goal, we used an adaptive management approach and attempted to improve growth and size of F-LMB by stocking additional prey fish and removing F-LMB to reduce density as needed.

\section{Materials and Methods}

\subsection{Fish Stocking and Ponds}

Largemouth bass brood stock to produce F-LMB was obtained from the E. W. Shell Fisheries Center at Auburn University, Alabama. These brood fish were collected from established populations ( $>30$ years) that are inter- 
grade hybrids between northern largemouth bass (M. s. salmoides) and Florida largemouth bass (M. s. floridanus). Feed-trained largemouth bass fingerlings were stocked into 0.04 -ha ponds and fed a $40 \%$ commercial protein diet twice a day. One year later at age 1, these fish were $>200 \mathrm{~mm}$, and many fish were sexually mature. Females were separated from males by inserting a capillary tube into the urogenital pore and classified as females if eggs or ovarian tissue were detected [13]. After fish were separated by sex, age-1 F-LMB were held in ponds and were given pelleted feed until these fish were stocked into experimental ponds.

Three trials were conducted in two ponds located at the E. W. Shell Fisheries Center between 2006 and 2013 (Table 1). In pond S-15, two trials were conducted; trial 1 started in October 2006 and ended in January 2009, and trial 2 was conducted from March 2009 through spring 2013. Trial 3 was conducted in pond S-5 from March 2008 through spring 2013. A total of 80, 80, and 20 presumed F-LMB were stocked (38 - 40 fish/ha, 6 $19 \mathrm{~kg} / \mathrm{ha}$ ) for evaluation in trials 1, 2, and 3, respectively (Table 1). Prior to stocking, each fish was measured, weighed, and injected with a Passive Transponder Tag (PIT) to allow for individual identification. Sunfish (Lepomis spp.) were stocked prior to F-LMB stockings in each trial (Table 1). In S-15 during both trials, water-soluble fertilizer (10-52-4) was applied during the growing season (April to October) to enhance phytoplankton growth with a goal to maintain water clarity (secchi transparency) at 0.5 to $0.7 \mathrm{~m}$ [16]. Fertilizer was not applied to S-5 (trial 3), as a phytoplankton bloom existed naturally on this pond and water clarity was $<0.8 \mathrm{~m}$ throughout the duration of this trial.

\subsection{Fish Sampling}

In each trial, F-LMB were periodically collected using DC electrofishing and angling, with most sampling occurring in February-April (spring) and October and November (fall) of each year. Totals of 111, 204, and 52 recaptures of stocked F-LMB were made over time in trials 1, 2, and 3 respectively. Of these fish, 189 were recaptured with angling, 139 with electrofishing, and 39 fish were obtained with rotenone (2 mg/L at $5 \%$ active ingredient) when the S-15 pond was renovated at the termination of trial 1 in January 2009. During sampling, F-LMB were measured for TL (mm), weighed (g), and the PIT number was recorded. If multiple recaptures of an individual fish occurred during a sampling season, then TL and weight of the first recapture was used in the analyses. Prey fish, including bluegill, redear sunfish (Lepomis microlophus), golden shiner (Notemigonus crysoleucas), threadfin shad (Dorosoma pentenense), and Nile tilapia (Oreochromis niloticus) were not collected, but occurrence was noted. In trial 1, golden shiners were stocked into this pond 9 months after F-LMB were stocked (Table 1). Additional prey fish were stocked in 2011 and 2012 during trial 2 in an attempt to increase F-LMB growth and relative weights (Table 1). Additional prey fish were not added to the trial 3 experiment.

\subsection{Data Analyses}

Growth, in length and weight, and relative weight were plotted using box plots that visualized these distributions over time when at least 8 fish were collected during a sampling event. Growth of F-LMB from age 1 to age 6 was compared to populations from three distinct regions. These included 1) fast-growing female Florida largemouth bass (one SD above mean length-at-age) populations that were aged with otoliths [17]; 2) average growth

Table 1. Description of pond morphometry (max = maximum), stocking history, lengths, and weights of female largemouth bass (F-LMB).

\begin{tabular}{|c|c|c|c|c|c|c|c|}
\hline $\begin{array}{l}\text { Pond } \\
\text { (trial) }\end{array}$ & $\begin{array}{l}\text { Area } \\
\text { (ha) }\end{array}$ & $\begin{array}{l}\text { Mean (max) } \\
\text { depth (m) }\end{array}$ & $\begin{array}{l}\text { Date F-LMB } \\
\text { stocked }\end{array}$ & $\begin{array}{l}\text { Density F-LMB } \\
\text { stocked (N/ha) }\end{array}$ & $\begin{array}{l}\text { Mean length F-LMB } \\
\text { (range) mm TL }\end{array}$ & $\begin{array}{l}\text { Mean weight } \\
\text { F-LMB (range) g }\end{array}$ & $\begin{array}{l}\text { Forage fish stocked } \\
\text { (time) }\end{array}$ \\
\hline S-15 (1) & 2.02 & $1.8(4.0)$ & Oct 2006 & 40 & $317(265$ - 369) & $493(283-725)$ & $\begin{array}{l}3700 \text { BGS/ha (May 2006) } \\
2200 \text { GDS/ha (Jun 2007) }\end{array}$ \\
\hline S-15 (2) & -- & -- & Mar 2009 & 40 & $221(194-264)$ & $177(116$ - 267) & $\begin{array}{c}4900 \text { BGS and RES/ha (Feb 2009) } \\
50 \text { TFS/ha (Jun 2011) } \\
\text { 13,000 TIL/ha (Jun 2012) }\end{array}$ \\
\hline S-5 (3) & 0.52 & $1.6(3.4)$ & Mar 2008 & 38 & $211(200-231)$ & $158(124-220)$ & 3800 BGS/ha (Nov 2007) \\
\hline
\end{tabular}

${ }^{\mathrm{a}}$ Forage fish; Tria1 1-bluegill sunfish Lepomis macrochirus (BGS) 75 - 100 mm TL; golden shiners Notemigonus crysoleucas (GDS) 100 - 125 mm TL; Tria1 2-bluegill sunfish (BGS) and redear sunfish L. microlophus (RES) 75 - 100 mm TL; Threadfin shad Dorosoma pentenense (TFS) 120 140 mm TL; Nile tilipia Oreochromis niloticus (TIL) 25 - 75 mm TL; Tria1 3-bluegill sunfish (BGS) 75 - 100 mm TL. 
for intergrade northern largemouth bass $\times$ Florida largemouth bass females that were aged with otoliths collected from Lake Seminole (Georgia-Florida-Alabama reservoir, data in [18] [19]), and nine Alabama reservoirs (Alabama Division of Wildlife and Freshwater Fish, unpublished data); and 3) known-age female largemouth bass (intergrade northern largemouth bass $\times$ Florida largemouth bass) collected from a Georgia public fishing pond (43 ha) that contained primarily F-LMB [15]. Relative weights of F-LMB were computed using the standard weight equation [20].

Program MARK [21] estimated survival and recapture rates, and population size using the POPAN utility which provides a parameterization of the Jolly-Seber model [22]. This model is robust for closed populations similar to our pond trials. We estimated apparent annual survival rates $(\varphi)$, recapture probabilities $(\rho)$, and super-population size $(N)$. Weighted Akaike's Information Criterion $\left(\mathrm{AIC}_{\mathrm{c}}\right)$ values, maximum likelihood values, and the differences in $\mathrm{AIC}_{\mathrm{c}}$ values $\left(\triangle \mathrm{AIC}_{\mathrm{c}}\right)$ were used to select the most suitable model [23] in each trial.

We ran a series of four general models [24] that included 1) single and constant estimates of $\varphi($.$) and \rho() ; 2$. constant $\varphi($.$) and annual time varying \rho(t)$; 3) annual time varying $\varphi(t)$ and constant $\rho($.$) ; and 4) annual time$ varying $\varphi(t)$ and $\rho(t)$. For all models, PENT (probability of entry) was fixed at zero as recruits from reproduction or immigration to adult F-LMB size did not occur over time. We used the link function logit in Program MARK to estimate $\varphi, \rho$, and $N$. For trial 1, F-LMB were stocked in October 2006, and $\varphi$ was estimated in spring 2007, and was reported as an annual survival rate. In trial 2, we removed F-LMB in spring 2012 in an attempt to increase growth rates. Thus, $\varphi$ in this trial was only estimated to spring 2012, but $N$ was estimated in spring 2013 using POPAN.

Finally, population and survival estimates computed from POPAN were compared to either the final number or minimum number of F-LMB recovered or observed when these trials were terminated. The instantaneous annual mortality rates $(Z)$ for each trial were estimated from the equation:

$$
Z=-\log _{\boldsymbol{e}}(\text { number recovered/number stock }) / \text { time }
$$

where the number recovered were either the final or minimum number of F-LMB obtained or observed at the termination of each trial, number stocked was the number of F-LMB stocked at the start of each trial, and time was the length of each trial in years. Annual survival rate (S) was estimated from:

$$
\mathrm{S}=\mathrm{e}^{-(\mathrm{z})}
$$

Annual survival rates were compared between POPAN estimates and the final/minimum number of F-LMB observed at the end of each trial.

\section{Results}

\subsection{Success of Sex Determination}

A total of 180 presumed F-LMB were stocked in these three trials, and of these fish, we detected only one male that was stocked into pond S-15 during trial 1. In fall 2008, we collected young largemouth bass in pond S-15. Thus, successful reproduction occurred during the second year after stocking in trial 1 . We recovered $8.4 \mathrm{~kg} / \mathrm{ha}$ and 133 fish/ha of age-1 largemouth bass (range 109 - $170 \mathrm{~mm} \mathrm{TL}$ ) during renovation of this pond in January 2009. Otolith examination of some of these longer young largemouth bass indicated these fish were hatched in spring 2008. We recovered 40 presumed adult F-LMB, and dissection showed one of these fish was a male. Prior to 2008, no young largemouth bass were observed while electrofishing in S-15. Likewise, no young largemouth bass were observed while collecting electrofishing samples in trials 2 and 3 . Therefore, we correctly identified $99.4 \%$ of the F-LMB stocked based the assumption that all stocked largemouth bass were females in trials 2 and 3, and one male fish was stocked and later collected in trial 1. Since this one male fish could be individually identified from the PIT tag number over time, this fish was not included when estimating growth, relative weight, survival, density, and biomass.

\subsection{Growth and Relative Weight}

Growth was rapid in all three trials during the first 1.5 to 2 years after stocking as age-3 F-LMB reached an average of 429 to $459 \mathrm{~mm}$ TL and weights of 1.37 to $1.66 \mathrm{~kg}$ (Figure 1). During this time, $\mathrm{W}_{\mathrm{r}} \mathrm{s}$ were generally high and varied from 100 to 140 except in fall 2009 during trial 3. In trial 1 between spring 2008 and January 2009, mean weight declined $0.3 \mathrm{~kg}$, growth in length was nil, and average $\mathrm{W}_{\mathrm{r}}$ declined from 121 to 97 (Figure 1). 


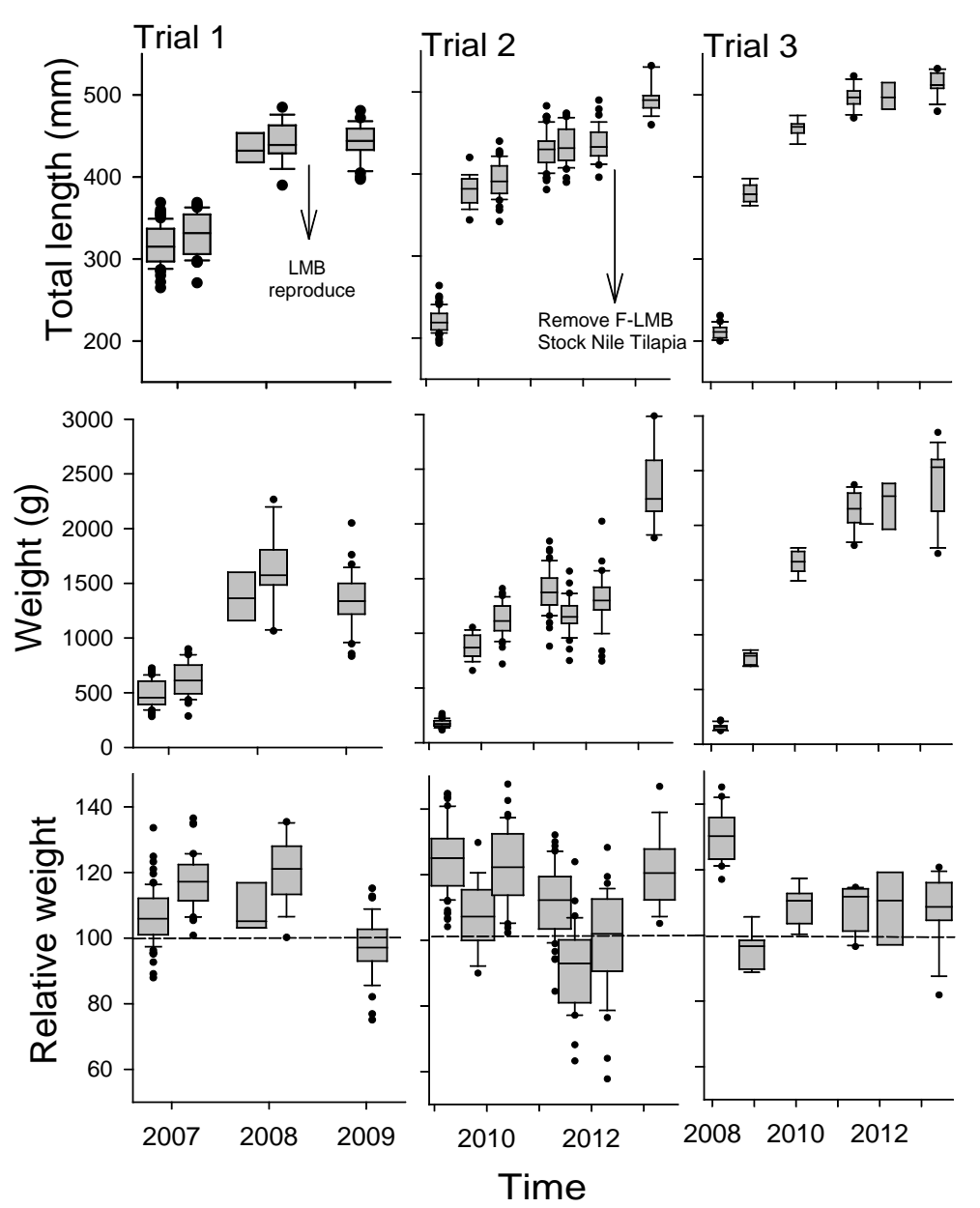

Figure 1. Distributions of female largemouth bass (F-LMB) lengths, weights, and relative weights over time for trial 1 (left column), trial 2 (middle column), and trial 3 (right column). Shaded areas represent lower and upper $25^{\text {th }}$ and $75^{\text {th }}$ percentiles, and the line in the shaded box is the median for each distribution. Error bars represent the $10^{\text {th }}$ and $90^{\text {th }}$ percentile and the dots are extreme low and high observations for each distribution. Largemouth bass successfully reproduced in spring 2008 in trial 1, in spring 2012, F-LMB density was reduced and Nile tilapia were stocked in trial 2, and these events are indicated in the top panels of trial. Relative weights of 100 were drawn across distributional graphs for reference.

This weight loss of F-LMB coincided with successful largemouth bass reproduction in spring 2008. The largest F-LMB produced in trial 1 was $485 \mathrm{~mm}$ TL and $2.27 \mathrm{~kg}$, and was an age-3 fish (Figure 1).

In trial 2, growth of age- 3 to age-4 F-LMB was nil 2 to 3 years after stocking and $\mathrm{W}_{\mathrm{r}}$ declined during this time (Figure 1). We stocked about 100 adult threadfin shad in this pond in June 2011 and schools of threadfin shad were observed in fall 2011, but neither growth nor $\mathrm{W}_{\mathrm{r}}$ of F-LMB increased (Figure 1). Therefore, in spring 2012, we removed 15 F-LMB (total weight $18.5 \mathrm{~kg}$ ), and stocked 13,000 Nile tilapia (25 - $75 \mathrm{~mm}$ TL) in June 2012. Removal of F-LMB constituted a 30\% reduction in biomass and density, based on the estimate of abundance in spring 2012. Between spring 2012 and 2013, average $\mathrm{W}_{\mathrm{r}}$ of F-LMB increased from about 100 to 120, and average weight and TLs increased from 1.30 to $2.34 \mathrm{~kg}$ and from 436 to $492 \mathrm{~mm}$, respectively (Figure 1). By spring 2013, 18\% of these age-5 F-LMB reached memorable length and the largest fish observed was $532 \mathrm{~mm}$ TL and $2.99 \mathrm{~kg}$.

In contrast to other trials, F-LMB growth in trial 3 continued to be relatively fast after age 3; average fish size at age 4 was $485 \mathrm{~mm}$ TL and $2.12 \mathrm{~kg}, 3$ years after stocking (Figure 1). After this time, growth was not as rapid, but still continued as age-6 F-LMB averaged $514 \mathrm{~mm}$ TL and $2.39 \mathrm{~kg}$ in spring 2013 when this trial terminated. Of the 13 F-LMB collected in spring 2013, 11 (85\%) of these age-6 fish had reached memorable length and the heaviest individual was $2.85 \mathrm{~kg}$. 
In all three trials, F-LMB grew faster than largemouth bass females collected in Lake Seminole and nine Alabama reservoirs (Figure 2). Growth up to age 5 was faster or similar for F-LMB in our study (Figure 2) compared to fast-growing female Florida largemouth bass collected from Florida. At age 6, fast-growing female Florida largemouth bass were slightly longer than F-LMB (Figure 2). After age 2, lengths-at-age of F-LMB stocked into a small Georgia impoundment were greater than our observed lengths-at-age (Figure 3).

\subsection{Survival, Density, and Biomass}

Apparent annual survival rates of F-LMB were 0.78, 0.86, and 0.93 in trials 1, 2, and 3, respectively (Table 2). From examination of weighted $\mathrm{AIC}_{\mathrm{c}}$ values, maximum likelihood values, and the differences in $\mathrm{AIC}_{\mathrm{c}}$ values $\left(\Delta \mathrm{AIC}_{\mathrm{c}}\right)$, varying $\rho$ each year with constant $\varphi$ displayed the most support as parsimonious models to estimate $\varphi$, $\rho$, and $\mathrm{N}$ in all three trials (Table 3). In trials 1 and 2, some support was evident for varying both $\rho$ and $\varphi$ each year (Table 3). However average time-varying $\varphi$ for trials 1 and 2 were 0.80 (range 0.65 - 0.92) and 0.85 (range 0.80 - 0.93), respectively, very similar to the constant values of $\varphi$ estimated by the two models that showed the most support. Recapture probabilities $(\rho)$ were high, averaging 0.62 among these three trials (range 0.24 - 0.93 ) resulting in relatively narrow confidence intervals about survival estimates (Table 2).

Average annual survival rates estimated by POPAN were similar to those survival rates computed from either recovered fish in each pond or the minimum number of unique individuals captured at the end of each trial. Rotenone was applied to terminate trial 1 and over a 3-day pick up, 39 F-LMB were recovered (Table 2). In trials 2 and 3, 42 and 13 individual F-LMB were collected in spring 2012 and spring 2013. Thus, average annual survival rates of F-LMB were at least $0.75,0.81$, and 0.92 in trials 1 , 2, and 3, respectively, very similar to survival rates estimated by POPAN (Table 2).

Density of F-LMB in these ponds was obviously inversely related to survival as highest densities over time were observed in trial 3 and the lowest in trial 2 after 15 F-LMB were removed three years after stocking (Figure 3). Biomass of F-LMB in trials 1 and 2 peaked at $40-43 \mathrm{~kg} / \mathrm{ha} 1.5$ to 2.0 years after stocking, then declined due to mortality and loss in fish weight 1.5 to 2.5 years after stocking (Figure 3). In trial 2, 15 F-LMB were removed in spring 2012 to lower density, but the increase in growth and greater weight of F-LMB four years after stocking did not result in biomass approaching values observed two years after stocking (Figure 3).

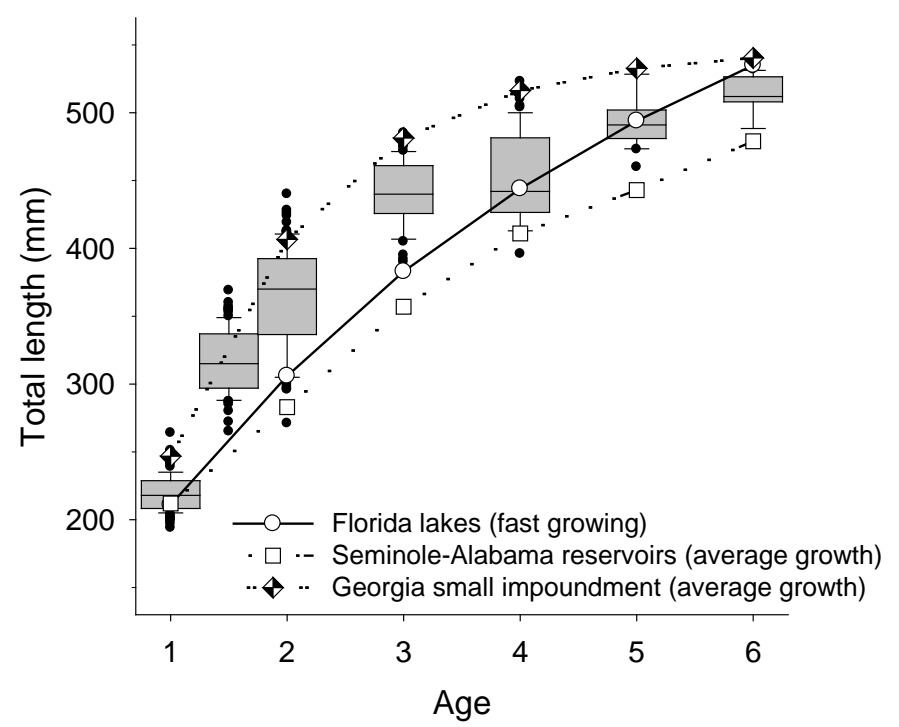

Figure 2. Distributional plots of female largemouth bass (F-LMB) total lengths against age where age 1 and age 1.5 fish represent stocked fish. Total lengths were pooled for each of the three trials. Shaded areas represent lower and upper $25^{\text {th }}$ and $75^{\text {th }}$ percentiles, the line in the shaded box is the median, error bars represent the $10^{\text {th }}$ and $90^{\text {th }}$ percentile, and the dots are extreme low and high observations for each length distribution. Mean lengths-at-age are shown for 1) fast-growing female largemouth bass from Florida; 2) for female largemouth bass from Lake Seminole, Georgia which represent intergrade populations (northern largemouth bass $\times$ Florida largemouth bass; and 3) for female largemouth bass collected from a small Georgia impoundment. 


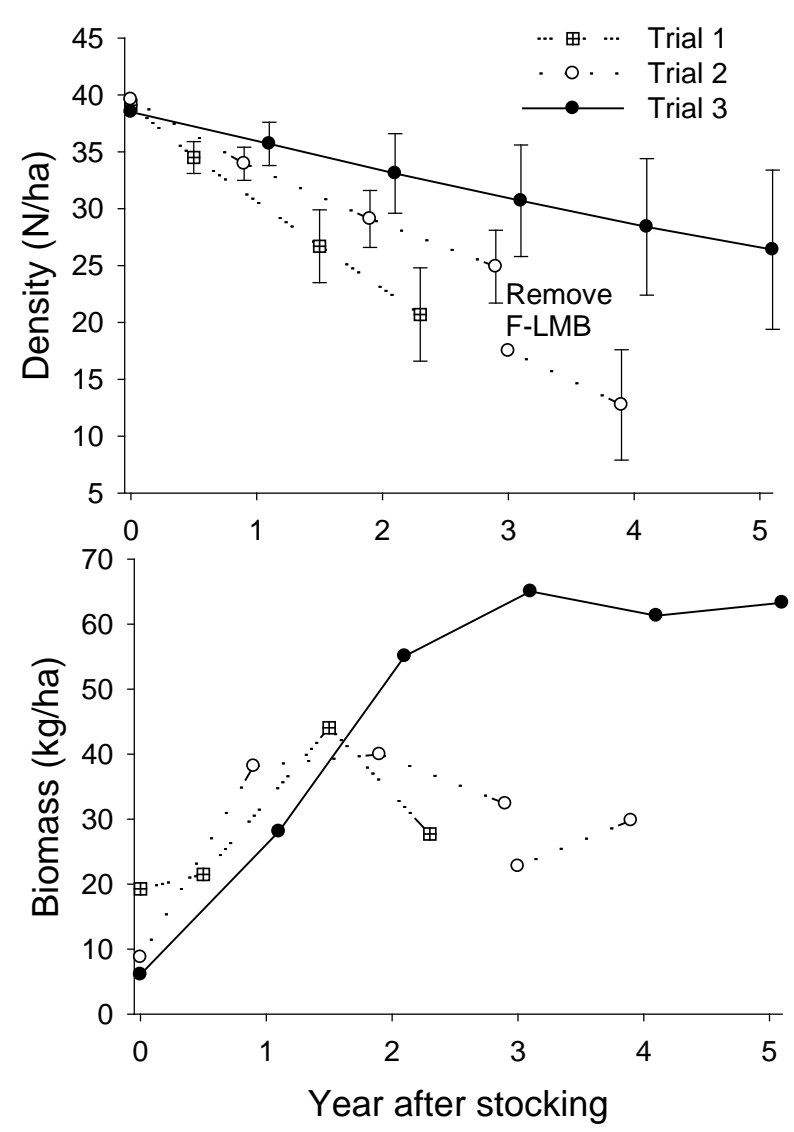

Figure 3. Density and biomass of female largemouth bass (F-LMB) plotted against years after stocking for the three experimental trials. Vertical bars associated with density represent the 95\% confidence intervals estimated by POPAN. In trial 2, 15 F-LMB were removed three years after stocking and density and biomass was adjusted from the population estimate after stocking occurred three years earlier.

In trial 3, F-LMB biomass was $55 \mathrm{~kg} /$ ha two years after stocking, and biomass remained relatively constant at 62 - $65 \mathrm{~kg} / \mathrm{ha}$ three to five years after stocking, suggesting F-LMB carrying capacity was reached.

\section{Discussion}

In two of three pond trials, we successfully established pure F-LMB populations and largemouth bass reproduction was not observed. The success of creating a non-reproducing largemouth bass fishery in ponds with female fish depends on correct sex identification of stocked fish and isolation of the drainage basin so males cannot enter the pond. We successfully sexed $99.4 \%$ of the largemouth bass examined. Sex was correctly identified for $97 \%$ of fish examined with a catheter [13], while $98 \%$ of the largemouth bass examined were accurately sexed using a probe and distance inserted in the urogenital pore [25]. Ultrasound correctly (100\%) identified the sex of mature channel catch (Ictalurus punctatus) greater than $0.9 \mathrm{~kg}$, but was imperfect $(50 \%-90 \%)$ for other species and sizes of fish [14]. In a Georgia impoundment, misidentification of sex occurred for stocked F-LMB which were presumed to be all females and resulted in largemouth bass reproduction [15]. Certainly, non-lethal techniques to insure $100 \%$ accuracy of sex differentiation need to be developed in the future for all F-LMB stockings to be a viable and widely-used management strategy.

The consequences of imperfect gender identification can be severe. In trial 1, the presence of at least one male fish allowed successful reproduction and resulted in a decline of about $20 \%$ in weight of F-LMB in less than one year. We recovered 133 age-1 largemouth bass/ha and this density was about three times higher than the density of age-1 F-LMB originally stocked into our experimental ponds. Without reducing the abundance of these small largemouth bass and/or stocking additional prey fish, we suspect that growth of F-LMB would not have continued over time in trial 1. 
Table 2. Trial numbers, stocking and termination dates for female largemouth bass (F-LMB). Number represents number stocked and population estimates and 95\% confidence intervals (95\% CIs). Apparent annual survival rates ( $\varphi \pm 95 \%$ CI) are given. The final or minimum number of F-LMB recovered from each trial and corresponding annual survival rates are also given. Note that $95 \%$ CIs were not computed for the initial population size as stocking numbers were known.

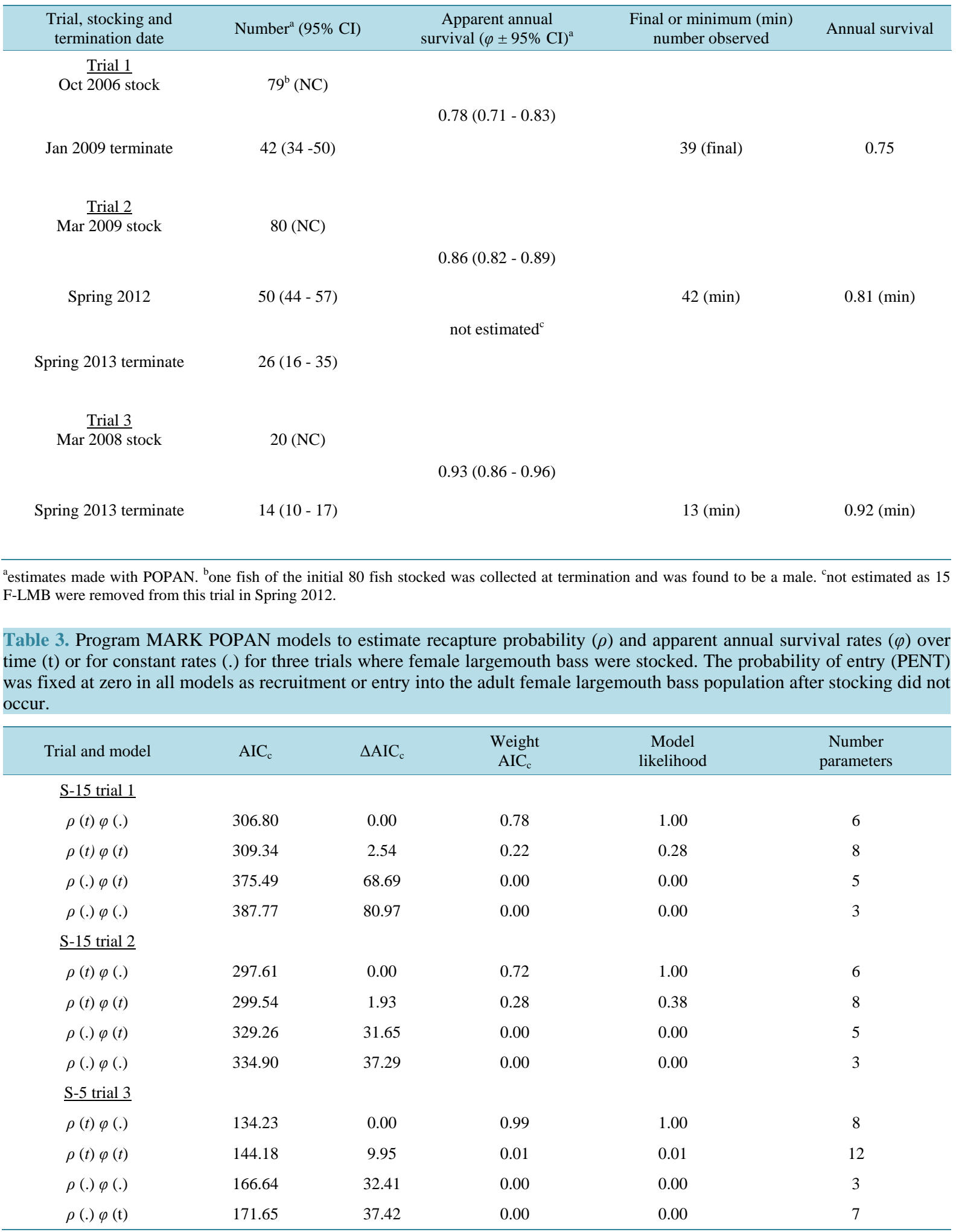


Overall annual survival rates among our three trials averaged 0.86; thus annual mortality (AM) was 0.14, and since fish were not harvested, the average instantaneous natural mortality rate $\left(M ; M=1-\boldsymbol{e}^{A M}\right.$ ) was 0.15 (range 0.07 to 0.25 ). Based on high recapture rates and either recovered or minimum number of fish observed at the end of each trial, this low mortality estimate is likely very accurate. Data or published estimates of $M$ for female largemouth bass currently do not exist. Analyses and reviews of mixed-sex largemouth bass population demographics in larger southern USA water bodies [17] [26]-[29] reported much higher $M$ values (range 0.30 to 0.64) compared to our estimates of $M$ for F-LMB. In small Alabama and Georgia impoundments, $M$ ranged from 0.10 to 0.61 (average 0.30) in mixed gender largemouth bass populations [30] [31]. Differences in water body size and type, aging and sampling techniques, presence of fishing mortality, and analytical methods to estimate $M$ possibly were factors related to this disparity. In addition, spawning and associated stress did not occur for F-LMB, and possibly contributed to lower $M$. Finally, longevity of female Florida largemouth bass was greater than males [32] [33]; hence $M$ should be lower for females [34]. Similarly, annual mortality of male Florida largemouth bass was greater than females [35].

Although $\mathrm{W}_{\mathrm{r}} \mathrm{s}$ over 100 are typically considered good body condition and are often related to faster growth [20], F-LMB at times displayed $\mathrm{W}_{\mathrm{r}}$ values of about 100, yet growth in weight and length was nil. Declines in $\mathrm{W}_{\mathrm{r}}$ of F-LMB in trials 1 and 2, were associated with little or no growth and suggested lack of adequate prey resources. Stocking adult threadfin and their subsequent reproduction in trial 2 did not result in continued growth or increase in $\mathrm{W}_{\mathrm{r}}$. However, reducing the density of F-LMB in this trial by about 30\% and stocking fingerling Nile tilapia resulted in a dramatic increase in $\mathrm{W}_{\mathrm{r}}$ and growth. To maintain trophy largemouth bass fisheries in ponds, some harvest of fish $>400 \mathrm{~mm}$ TL may be needed [4]. Examination of the relation between $\mathrm{W}_{\mathrm{r}} \mathrm{s}$ and growth suggested that $\mathrm{W}_{\mathrm{r}}$ s over 110 were typically associated with continued F-LMB growth in our trials. Similarly in a Georgia impoundment, $\mathrm{W}_{\mathrm{r}} \mathrm{s}$ of all sizes of F-LMB averaged 119 at the termination of this experiment and growth was rapid for these fish [15]. A management scenario proposed for a "trophy largemouth bass option" [4] included a recommended $\mathrm{W}_{\mathrm{r}}$ of at least 105 for largemouth bass, similar to our observations.

The reduction in density of F-LMB and stocking additional prey fish in trial 2 resulted in a nearly a two-fold increase in weight of F-LMB after only one year. This suggested that possibly lower F-LMB stocking densities and stocking additional prey fish will increase growth rates and maximum size of F-LMB. In a newly renovated impoundment (43 ha) in Georgia, $13 \mathrm{~F}-\mathrm{LMB} \cdot \mathrm{ha}^{-1} \cdot \mathrm{yr}^{-1}$ were stocked the first two years (lower than the rates we used) and over 1 million prey fish of varying sizes and species were added over time [15]. This lower stocking density combined with high stocking rates of prey fish in this Georgia impoundment [15] resulted in faster F-LMB growth and larger maximum sizes (>3.6 kg) than we observed.

In a moderately productive pond, about $50 \mathrm{~kg} / \mathrm{ha}$ of largemouth bass was considered a reasonable maximum biomass [4]. Biomass of F-LMB inhabiting our ponds was similar to those found in other ponds which contained mixed gender largemouth bass. In a survey of 166 ponds throughout the USA, average largemouth bass biomass was $56 \mathrm{~kg} / \mathrm{ha}$ [1]. In 38 Missouri ponds, largemouth bass biomass ranged from 3 to $112 \mathrm{~kg} /$ ha and averaged 43 kg/ha [36]. Harvestable-size (about $25 \mathrm{~cm}$ ) largemouth bass averaged 27 and $32 \mathrm{~kg} / \mathrm{ha}$ from a survey of Kentucky and Oklahoma ponds; respectively [37] [38].

In these experiments, we attempted to reproduce actual pond management practices. Thus, forage fish were added, F-LMB removed, and ponds fertilized as needed based upon performance of each trial towards attaining our objectives through this adaptive management strategy. This was similar to the process undertaken by many private pond owners, consultants, and state fish conservation agencies who manage fishery resources in ponds [4] [6] [16]. Thus, results from this study should be directly applicable for managers working with small ponds.

Stocking and maintenance of all F-LMB populations offers an attractive alternative to create low-density, fast-growing, quality largemouth bass fisheries in ponds. Based on our previous research [7] [8] and observations from this study, eliminating and greatly reducing largemouth bass recruitment is the most promising management technique to provide for long-term sustainable populations that contain only larger and faster growing fish. For F-LMB, survival and growth rates were very high with many fish exceeding 450 mm TL only two years after stocking. Growth rates of F-LMB in our trials exceeded female largemouth growth when compared to other mix-sexed populations in southeastern USA with the exception of older fish (age 5 to 6) from Florida. In trial 3, we created a sustainable fishery of desirable-sized F-LMB with no maintenance as this pond was neither fertilized nor additional prey fish stocked. An initial maximum stocking rate of 40 fish/ha is recommended to achieve a quality F-LMB population, lower stocking rates without stocking additional forage fish may produce larger fish, but warrants further research. In a Georgia impoundment, lower stocking rates of F-LMB were 
associated with faster growth and larger maximum sizes [15], but this occurred with higher stocking densities of forage fish than we employed. We found that removal of F-LMB may be necessary to maintain growth especially if $\mathrm{W}_{\mathrm{r}}$ declines below 105 . Stocking F-LMB in suitable ponds is a management strategy ideal for catchand-release fishing, and can quickly provide a fishery dominated by larger fish.

\section{Acknowledgements}

Funding for this project was provided by a gift from W. R. Ireland to the School of Fisheries, Aquaculture, and Aquatic Science. Pond fertilizer was kindly provided by Southeastern Pond Management, Calera, Alabama. E. Peatman conducted genetic analysis to classify F-LMB and M. Catalano assisted with Program MARK analysis. J. Slipke and T. Bonvechio provided comments to improve this paper. A host of former and current Auburn University students and staff assisted with field collections.

\section{References}

[1] Willis, D.W. and Neal, J.W. (2012) Small Impoundments and the History of Their Management. In: Neal, J.W. and Willis, D.W., Eds., Small Impoundment Management in North America, American Fisheries Society, Bethesda, Maryland, 3-20.

[2] US Department of Interior, Fish and Wildlife Service, and US Department of Commerce, US Census Bureau (1993) 1991 National Survey of Fishing, Hunting, and Wildlife-Associated Recreation, Washington, DC. http://www.census.gov/prod/www/fishing.html

[3] Willis, D.W., Lusk, R.D. and Slipke, J.W. (2010) Farm Ponds and Small Impoundments. In: Hubert, W.A. and Quist, M.C., Eds., Inland Fisheries Management in North America, American Fisheries Society, Bethesda, Maryland, 501544.

[4] Schramm Jr., H.L. and Willis, D.W. (2012) Assessment and Harvest of Largemouth Bass-Bluegill Ponds. In: Neal, J.W. and Willis, D.W., Eds., Small Impoundment Management in North America, American Fisheries Society, Bethesda, Maryland, 181-213.

[5] Dauwalter, D.C. and Jackson, J.R. (2005) A Re-Evaluation of US State Fish-Stocking Recommendations for Small, Private, Warmwater Impoundments. Fisheries, 30, 18-28. http://dx.doi.org/10.1577/1548-8446(2005)30[18:AROUSF]2.0.CO;2

[6] Wright, R.A. and Kraft, C.E. (2012) Stocking Strategies for Recreational Small Impoundments. In: Neal, J.W. and Willis, D.W., Eds. Small Impoundment Management in North America, American Fisheries Society, Bethesda, Maryland, 155-180.

[7] Sammons, S.M. and Maceina, M.J. (2005) Population Size, Survival, and Growth of Largemouth Bass One Year after Stocking in Four Ponds. Proceedings of the Southeastern Association Fish and Wildlife Agencies, 59, 241-250.

[8] Maceina, M.J. and Sammons, S.M. (2015) Stocking Threadfin Shad to Enhance Largemouth Bass Populations in Two Alabama Ponds. Journal of the Southeastern Association Fish and Wildlife Agencies, 2, 28-34.

[9] Gabelhouse Jr., D.W. (1987) Responses of Largemouth Bass and Bluegill to Removal of Surplus Largemouth Bass from a Kansas Pond. North American Journal of Fisheries Management, 7, 81-90. http://dx.doi.org/10.1577/1548-8659(1987)7<81:ROLBAB >2.0.CO;2

[10] Slipke, J.W. and Sammons, S.M. (2012) Pond Renovation. In: Neal, J.W. and Willis, D.W., Eds., Small Impoundment Management in North America, American Fisheries Society, Bethesda, Maryland, 235-250.

[11] Garrett, G.P., Birkner, M.C.F. and Gold, J.R. (1992) Triploidy Induction in Largemouth Bass, Micropterus salmoides. Journal of Applied Aquaculture, 1, 27-34. http://dx.doi.org/10.1300/J028v01n03 02

[12] Neal, J.W. and Noble, R.L. (2008) Comparison of Diploid and Triploid Largemouth Bass Growth and Maturation Through Age 1 in Puerto Rico. North American Journal of Fisheries Management, 28, 688-693. http://dx.doi.org/10.1577/M07-046.1

[13] Ross, R.M. (1984) Catheterization: A Non-Harmful Method of Sex Identification for Sexually Monomorphic Fishes. The Progressive-Fish Culturist, 46, 151-152. http://dx.doi.org/10.1577/1548-8640(1984)46<151:C>2.0.CO;2

[14] Jennings, C.A., Sloss, B.L., Lasee, B.A., Burtle, G.J. and Moyer, G.R. (2012) Care, Handling, and Examination of Sampled Organisms. In: Zale, A.V., Parrish, D.L. and Sutton, T.M., Eds., Fisheries Techniques, American Fisheries Society, Bethesda, Maryland, 163-221.

[15] Bonvechio, T.F. and Rydell, J.J. (2016) Use of a Female-Only Stocking Strategy to Establish a Trophy Largemouth Bass in a Small Georgia Impoundment. Journal of the Southeastern Association of Fish and Wildlife Agencies, 3, 136143. 
[16] Stone, N., Morris, J.E. and Smith, B. (2012) Managing the Pond Environment. In: Neal, J.W. and Willis, D.W., Eds., Small Impoundment Management in North America, American Fisheries Society, Bethesda, Maryland, 113-152.

[17] Allen, M.S., Shaeffer, W., Porak, W.F. and Crawford, S. (2002) Growth and Mortality of Largemouth Bass in Florida Waters: Implications for Use of Length Limits. In: Phillipp, D.P. and Ridgway, M.S., Eds., Black Bass: Ecology, Conservation, and Management, American Fisheries Society, Symposium 31, Bethesda, Maryland, 559-566.

[18] Brown, S.J. and Maceina, M.J. (2002) The Influence of Disparate Levels of Aquatic Vegetation on Largemouth Bass Population Characteristics in a Georgia Reservoir. Journal of Aquatic Plant Management, 40, 28-35.

[19] Sammons, S.M., Maceina, M.J. and Partridge, D.G. (2005) Population Characteristics of Largemouth Bass Associated with Changes in Abundance of Submersed Aquatic Vegetation in Lake Seminole, Georgia. Journal of Aquatic Plant Management, 43, 9-16.

[20] Neumann, R.M., Guy, C.S. and Willis, D.W. (2012) Length, Weight, and Associated Structural Indices. In: Zale, A.V., Parrish D.L. and Sutton, T.M., Eds., Fisheries Techniques, American Fisheries Society, Bethesda, Maryland, 637-676.

[21] White, G.C. and Burnham, K.P. (1999) Program MARK: Survival Estimation from Populations of Marked Animals. Bird Study, 46, S120-S139. http://dx.doi.org/10.1080/00063659909477239

[22] Schwarz, C.J. and Arnason, A.N. (1996) A General Methodology for the Analysis of Capture-Recapture Experiments in Open Populations. Biometrics, 52, 860-873. http://dx.doi.org/10.2307/2533048

[23] Burnham, K.P. and Anderson, D.R. (2002) Model Selection and Multimodel Inference: A Practical Information-Theoretic Approach. Springer-Verlag, New York.

[24] Phelps, Q.E., Vining, I., Herzog, D.P., Dames, R., Travnicheck, V.H., Tripp, S.J. and Boone, M. (2013) A Comparison of Methods to Estimate Shovelnose Sturgeon Mortality in the Mississippi River Adjacent to Missouri and Illinois. North American Journal of Fisheries Management, 33, 754-761. http://dx.doi.org/10.1080/02755947.2013.808291

[25] Benz, G.W. and Jacobs, R.P. (1986) Practical Field Methods of Sexing Largemouth Bass. The Progressive-Fish Culturist, 48, 221-225. http://dx.doi.org/10.1577/1548-8640(1986)48<221:PFMOSL >2.0.CO;2

[26] Beamesderfer, R.C.P. and North, J.A. (1995) Growth, Natural Mortality, and Predicted Response to Fishing for Largemouth Bass and Smallmouth Bass Populations in North America. North American Journal of Fisheries Management, 15, 688-704. http://dx.doi.org/10.1577/1548-8675(1995)015<0688:GNMAPR>2.3.CO;2

[27] Allen, M.S., Miranda, L.E. and Brock, R.E. (1998) Implications of Compensatory Mortality and Additive Mortality to the Management of Selected Sportfish Populations. Lake and Reservoirs: Research and Management, 3, 67-79. http://dx.doi.org/10.1111/j.1440-1770.1998.tb00033.x

[28] Allen, M.S., Walters, C.J. and Myers, R. (2008) Temporal Trends in Largemouth Bass Mortality, with Fishery Implications. North American Journal of Fisheries Management, 28, 418-427. http://dx.doi.org/10.1577/M06-264.1

[29] Dotson, J.R., Allen, M.S., Kerns, J.A. and Pouder, W.F. (2013) Utility of Restrictive Harvest Regulations for Trophy Largemouth Bass Management. North American Journal of Fisheries Management, 33, 499-507. http://dx.doi.org/10.1080/02755947.2013.769921

[30] Irwin, B.J., DeVries, D.R. and Wright, R.A. (2003) Evaluating the Potential for Predatory Control of Gizzard Shad by Largemouth Bass in Small Impoundments: A Bioenergetics Approach. Transactions of the American Fisheries Society, 132, 913-924. http://dx.doi.org/10.1577/T01-142

[31] Bonvechio, T.F., Bowen, B.R., Wilson, J.M. and Allen, M.S. (2014) Exploitation and Length Limit Evaluation of Largemouth Bass in Three Georgia Small Impoundments. Journal of the Southeastern Association Fish and Wildlife Agencies, 1, 33-41.

[32] Schramm Jr., H.L. and Smith, D.C. (1987) Differences in Growth Rate between Sexes of Florida Largemouth Bass. Proceedings of the Southeastern Association Fish and Wildlife Agencies, 41, 76-84.

[33] Porak, W., Coleman, S. and Crawford, S. (1987) Age, Growth, and Mortality of Florida Largemouth Bass Utilizing Otoliths. Proceedings of the Southeastern Association Fish and Wildlife Agencies, 40, 206-215.

[34] Hoenig, J.M. (1983) Empirical Use of Longevity Data to Estimate Mortality Rates. Fishery Bulletin, 82, 898-903.

[35] Crawford, S., Porak, W.F., Renfro, D.J. and Cailteux, R.L. (2002) Characteristics of Trophy Largemouth Bass Populations in Florida. In: Phillipp, D.P. and Ridgway, M.S., Eds., Black Bass: Ecology, Conservation, and Management, American Fisheries Society, Symposium 31, Bethesda, Maryland, 567-581.

[36] Hackney, P.A. (1978) Fish Community Biomass Relationships. In: Novinger, G.D. and Dillard, J.G., Eds., New Approaches to the Management of Small Impoundments, North Central Division, American Fisheries Society, Special Publication No. 5, 25-36.

[37] Jenkins, R.M. (1958) The Standing Crop of Fish in Oklahoma Ponds. Proceedings of the Oklahoma Academy of Science, 38, 157-172.

[38] Turner, W.R. (1960) Standing Crops of Fishes in Kentucky Farm Ponds. Transactions of the American Fisheries Society, 89, 333-337. http://dx.doi.org/10.1577/1548-8659(1960)89[333:SCOFIK]2.0.CO;2 